\title{
EFEKTIVITAS PEMBELAJARAN DARING DI MTS NEGERI 2 PURBALINGGA TAHUN PELAJARAN 2020/2021
}

\author{
ZAENAL KHAYAT \\ MTs Negeri 2 Purbalingga \\ e-mail : zaenal.key@gmail.com
}

\begin{abstract}
ABSTRAK
Penelitian ini bertujuan untuk menelisik efektivitas pembelajaran dengan menggunakan Whatsapp dan Google Classroom sebagai media pembelajaran dalam jaringan (daring) di MTs Negeri 2 Purbalingga, pada Masa Pandemi Covid-19 Tahun Pelajaran 2020/2021. Peneliti melakukan penelitian lapangan dengan pendekatan kualitatif deskriptif pada siswa dan guru MTs Negeri 2 Purbalingga. Hasilnya menunjukkan bahwa pembelajaran daring melalui Whatsapp dan Google Classroom pada MTs Negeri 2 Purbalingga kurang efektif, karena berbagai faktor baik dari siswa maupun dari guru. Sehingga sangat diperlukan evaluasi peran guru, siswa dan orang tua dalam meningkatkan efektivitas pembelajaran daring di MTs Negeri 2 Purbalaingga.
\end{abstract}

Kata kunci : Efektivitas belajar, Pembelajaran jarak jauh/Pembelajaran dalam jaringan, Whatsapp, Google Classroom

\section{PENDAHULUAN}

Masa pandemi Covid-19 di Indonesia membuat proses belajar mengajar di sekolah/madrasah berubah total. Kondisi ini mengakibatkan banyaknya kebijakan dalam proses pembelajaran di seluruh wilayah Indonesia, dari perkotaan sampai wilayah pedesaan, termasuk di Kabupaten Purbalingga. Pemerintah menutup dan menghimbau sekolah untuk mengganti proses pembelajaran tatap muka dengan pembelajaran jarak jauh atau pembelajaran dalam jaringan (daring).

Hal ini sesuai surat edaran yang diterbitkan Mendikbud Nomor 3 Tahun 2020 tentang pencegahan Covid-19 pada Satuan Pendidikan dan Nomor 36962/MPK.A/HK/2020 yang terhitung mulai tanggal 16 Maret 2020 memberlakukan pembelajaran secara daring dari rumah bagi siswa dan mahasiswa di seluruh provinsi. Selain itu, dengan pembelajaran sistem daring maka jenis pembelajaran bisa dipetakan yang cocok atau tidak cocok. Sistem ini melibatkan banyak pihak seperti guru, peserta didik, maupun orangtua untuk memantau kegiatan belajar anak selama di rumah.

Pembelajaran jarak jauh adalah proses pendidikan yang menjembatani keterpisahan antara siswa dengan pendidik dan dimediasi oleh pemanfaatan teknologi. Pendidikan jarak jauh ditawarkan lintas ruang dan waktu sehingga siswa memperoleh fleksibilitas belajar dalam waktu dan tempat yang berbeda, serta menggunakan beragam sumber belajar.

Istilah pembelajaran jarak jauh (PJJ) sekarang lebih familiar dengan istilah daring, yaitu pembelajaran dalam jaringan. Ada banyak media yang digunakan untuk belajar daring. Berbagai platform sudah lama menyediakan jasa ini. Sebut saja misalnya Google Clasroom, Rumah Belajar, Edmodo, Ruang Guru, Zenius, Google Suite for Education, Microsoft Office 365 for Education, Sekolahmu, Kelas Pintar. Inilah yang disebut sebagai platform microbloging (Basori, 2013). Namun perlu waktu untuk mempelajari sistem belajar melalui platform belajar daring tersebut.

Whatsapp dan Google Classroom adalah aplikasi pokok yang paling banyak dipilih dan digunakan di sekolah/madrasah, termasuk di MTs Negeri 2 Purbalingga. Pemilihan aplikasi tersebut tentu sudah melalui pertimbangan secara komprehensif, yaitu melihat kemudahan aplikasi, efektivitas, serta kemampuan guru dan siswa. Grup Whatsapp lebih difungsikan sebagai forum utama kelas untuk menyajikan berbagai informasi dari guru, baik berkaitan dengan pembelajaran maupun informasi kegiatan akademik lainnya. Sedangkan Google Classroom, lebih banyak difungsikan untuk penyajian materi dan evaluasi. 
Pertanyaan yang sering muncul adalah, bagaimana tingkat keberhasilan atau efektivitas pembelajaran jarak jauh di sekolah/madrasah? Tentu banyak perbedaan antara satu tempat dengan tempat lainnya, tergantung faktor pendukungnya. Karena, efektifitas pembelajaran tidak lain adalah usaha pembelajaran yang berkriteria daya tarik atau daya guna, artinya dengan pemanfaatan seperangkat media/alat pembelajaran, guru dapat menolong siswa mencapai tujuan pembelajaran. Dengan kata lain efektifitas adalah salah satu indikator dari proses pembelajaran yang baik.

Nisaul Choeroh (2020) menjelaskan bahwa efektivitas adalah suatu ukuran yang menyatakan seberapa jauh target (kuantitas, kualitas dan waktu) telah tercapai. Dimana makin besar presentase target yang dicapai, makin tinggi efektivitasnya. Sedangkan menurut Astim Riyanto (2003:6), efektivitas pembelajaran diartikan berhasil guna atau tepat guna, atau mencapai tujuan atau pencapaian tujuan pembelajaran.

Berkatian dengan efektivitas pembelajaran jarak jauh (daring), Moh. Ismail (2018), menyebutkan bahwa suatu pembelajaran jarak jauh (daring) antara lain harus memiliki unsur, 1) Menggunakan aplikasi yang mampu menjadikan sarana ini sebagai tempat kegiatan siswa di mana siswa dapat menambah kemampuan, membaca materi pelajaran, mencari informasi dan sebagainya; 2) Interaksi dalam group, para siswa dan guru dapat berinteraksi untuk mendiskusikan materi yang diberikan guru; 3) Sistem administrasi siswa, di mana para siswa dapat melihat informasi mengenai status siswa, prestasi siswa, dan sebagainya. Maka efektivitas pembelajaran akan dilihat dari tiga hal di atas. Yaitu (1) seberapa besar tingkat partisipasi anak dalam sebuah forum; (2) seberapa besar intensitas guru dalam menyampaikan informasi pembelajaran melalui forum online; dan (3) tingkat keberhasilan dalam mencapai tujuan pembelajaran.

Zimmerman dan Martinez-Pons (1990) menjelaskan jika seorang siswa bertanggung jawab dan dapat belajar secara efektif, maka ia akan mendapat prestasi yang baik dalam belajar. Hal tersebut juga bisa didapatkan dengan cara meregulasi diri dalam belajar atau self regulated learning.

Pembelajaran daring, idealnya harus dapat menggantikan pembelajaran tatap muka, dimana guru dan siswa hadir secara virtual melakukan proses belajar mengajar, menyampaikan materi, menyampaikan tugas, dan mengevaluasi. Namun, pembelajaran daring masih dianggap hanya memberikan tugas melalui internet dan bukan diartikan pembelajaran interaksi seperti halnya tatap muka.

Fenomena aktivitas belajar dalam jaringan dengan berbagai faktor kendala, jelas terasa di MTs Negeri 2 Purbalingga. Sehingga guru harus selalu berusaha mengefektifkan proses pembelajaran daring jika kondisi Pandemi Covid-19 belum membaik. Guru dan siswa dituntut untuk dapat merencanakan kegiatan belajarnya dengan baik, mengontrol waktu belajarnya, memiliki daya tahan dalam menyelesaikan tugas, dapat membuat penyajian materi belajar yang menyenangkan, ada tanggung jawab dan disiplin, serta bisa mengatur rencana dalam mencapai sasaran kompetensi atau tujuan pembelajaran.

Tujuan dari penelitian ini adalah untuk mengetahui tingkat keberhasilan atau efektivitas belajar daring melalui Whatsapp dan Google Classroom pada Masa Pandemi Covid-19 di MTs Negeri 2 Purbalingga, Tahun Pelajaran 2020/2021.

\section{METODE PENELITIAN}

Metode dalam penelitian ini adalah penelitian lapangan (field research) yang berusaha melihat realitas praktis penggunaan media Whatsapp dan Google Classroom sebagai media belajar daring di Kelas VII-D, VIII-A dam IX-G MTs Negeri 2 Purbalingga. Penelitian ini termasuk kualitatif deskriptif maka peneliti akan memanfaatkan data-data kualitatif kemudian dijabarkan secara deskriptif. Peneliti melakukan observasi, wawancara dan studi dokumen kepada beberapa guru, siswa dan orang tua sebagai sample penelitian untuk mendapatkan data. Observasi ini dimana peneliti sebagai Wakil Kepala Bidang Kurikulum (Akademik), melihat secara langsung bagaimana proses pembelajaran daring di MTs Negeri 2 Purbalingga Semester 
I (Gasal) Tahun Pelajaran 2020/2021. Sedang interview dilakukan kepada guru, siswa dan orang tua untuk mendalami proses belajar yang telah diobservasi.

Jumlah guru mata pelajaran yang mengajar di masing-masing kelas adalah 15 orang, sesuai dengan jumlah mata pelajarannya, sehingga keseluruhan berjumlah 43 orang guru. Sedangkan jumlah siswa Kelas VII-D adalah 32 anak, Kelas VIII-A sebanyak 36 anak, dan Kelas IX-G sebanyak 38 anak.

Efektivitas pemanfaatan media pembelajaran daring, dapat dilihat dari aktivitas guru, partisipasi siswa dan ketercapaian tujuan pembelajaran.

\section{HASIL PENELITIAN DAN PEMBAHASAN}

1. Penelitian terhadap Aktivitas Guru dalam Pemanfaatan Media Whatsapp dan Google Classroom dalam Pembelajaran Daring.

Survey dilakukan kepada 45 guru mata pelajaran di kelas VII-D, VIII-A dan IX-G MTs Negeri 2 Purbalingga, untuk memperoleh data tentang aktivitas guru dalam memanfaatkan media pembelajaran Whatsapp dan Google Classroom. Data berupa persentase pemanfaatan media Whatsapp dan Google Classroom dilihat dari banyaknya materi esensi di semester I (Gasal) masa pandemi Covid-19.

Dari 45 guru, survey menunjukkan bahwa 100\% guru telah memanfaatkan Whatsapp dan Google Classroom sebagai media pembelajaran daring di kelas VII-D, VIII-A dan IX-G MTs Negeri 2 Purbalingga. Namun pemanfaatannya belum maksimal.

Di Kelas VII-D, rata-rata pemanfaatan Whatsapp oleh guru mencapai 100\% dari jumlah materi esensi tiap mata peajaran. Sedangkan materi esensi yang disampaikan menggunakan Google Classroom hanya 52\%. Di Kelas VIII-A, rata-rata pemanfaatan Whatsapp oleh guru mencapai $100 \%$ dari jumlah materi esensi tiap mata peajaran. Sedangkan guru yang menggunakan Google Classroom hanya $62 \%$ dari jumlah materi esensi tiap mata pelajaran. Kelas IX-G, rata-rata pemanfaatan Whatsapp oleh guru mencapai $100 \%$, sedangkan Google Classroom hanya $67 \%$ dari jumlah materi esensi tiap mata pelajaran. Untuk lebih jelasnya dapat dilihat melalui Tabel berikut:

Tabel 1. Pemanfaatan Media Whatsapp dan Google Classroom untuk Menyajikan Materi Esensi di Kelas VII-D, VIII-A dan IX-G Semester I

\begin{tabular}{|c|c|c|c|c|c|c|c|c|c|c|c|c|c|}
\hline \multirow[b]{2}{*}{ No } & \multirow[b]{2}{*}{ Mapel } & \multicolumn{4}{|c|}{ KIs VII-D } & \multicolumn{4}{|c|}{ KIs VIII-A } & \multicolumn{4}{|c|}{ KIs IX-G } \\
\hline & & KD & Mtr & WA & GCR & KD & Mtr & $\overline{W A}$ & GCR & KD & Mtr & WA & GCR \\
\hline 1 & Quran Hadits & 4 & 12 & 12 & 8 & 4 & 12 & 12 & 8 & 4 & 12 & 12 & 8 \\
\hline 2 & Aqidah Aklak & 3 & 9 & 9 & 7 & 3 & 9 & 9 & 6 & 3 & 9 & 9 & 7 \\
\hline 3 & Fikih & 4 & 6 & 6 & 6 & 4 & 6 & 6 & 6 & 3 & 8 & 8 & 8 \\
\hline 4 & SKI & 4 & 6 & 6 & 6 & 4 & 6 & 6 & 6 & 3 & 8 & 8 & 8 \\
\hline 5 & $\mathrm{Pkn}$ & 3 & 9 & 9 & 7 & 3 & 9 & 9 & 6 & 3 & 9 & 9 & 7 \\
\hline 6 & B. Indonesia & 4 & 12 & 0 & 12 & 13 & 13 & 10 & 9 & 4 & 12 & 12 & 12 \\
\hline 7 & Bhs. Arab & 3 & 8 & 0 & 8 & 3 & 8 & 0 & 8 & 3 & 8 & 8 & 8 \\
\hline 8 & Matematika & 4 & 13 & 0 & 15 & 4 & 13 & 0 & 15 & 12 & 12 & 12 & 12 \\
\hline 9 & IPA & 5 & 5 & 5 & 5 & 3 & 9 & 9 & 6 & 5 & 5 & 5 & 5 \\
\hline 10 & IPS & 4 & 12 & 4 & 12 & 4 & 18 & 18 & 17 & 3 & 9 & 9 & 6 \\
\hline 11 & Bhs. Inggris & 4 & 8 & 8 & 6 & 4 & 8 & 8 & 6 & 4 & 8 & 8 & 5 \\
\hline 12 & Seni Budaya & 4 & 6 & 6 & 6 & 3 & 9 & 9 & 7 & 3 & 9 & 9 & 7 \\
\hline 13 & Penjas & 3 & 9 & 9 & 6 & 3 & 9 & 9 & 6 & 4 & 6 & 6 & 6 \\
\hline 14 & Prakarya & 3 & 6 & 6 & 6 & 3 & 6 & 6 & 6 & 3 & 6 & 6 & 6 \\
\hline 15 & Bahasa Jawa & 4 & 6 & 6 & 6 & 4 & 6 & 6 & 6 & 3 & 8 & 8 & 8 \\
\hline & Jumlah & 56 & 127 & 86 & 116 & 62 & 141 & 117 & 118 & 60 & 129 & 129 & 113 \\
\hline & Rata-rata & & & $68 \%$ & $91 \%$ & & & $83 \%$ & $84 \%$ & & & $100 \%$ & $88 \%$ \\
\hline
\end{tabular}

Berdasarkan data di atas, dari 15 mata pelajaran dengan jumlah $56 \mathrm{KD}$, dan jumlah materi esensi 127, diperoleh data $68 \%$ materi esensi di Kelas VII-D di sampaikan melalui media Whatsapp sedangkan 91,00\% materi esensi disampaikan melalui Google Classroom. Sedangkan untuk kelas VIII-A, dari 15 mata pelajaran dengan jumlah $62 \mathrm{KD}$, dan jumlah materi esensi 141, diperoleh data 83\% materi esensi di sampaikan melalui media Whatsapp sedangkan 84,00\% materi esensi disampaikan melalui Google Classroom. Sementara di kelas 
IX-G, derdasarkan data di atas, dari 15 mata pelajaran dengan jumlah $60 \mathrm{KD}$, dan jumlah materi esensi 129, diperoleh data $100 \%$ materi esensi di sampaikan melalui media Whatsapp sedangkan 88,00\% materi esensi disampaikan melalui Google Classroom. Berikut peneliti sajikan dalam bentuk grafik:

\section{Grafik 4. Pemanfaatan Media PJJ Whatsapp dan Google Classroom di Kelas VII-D, VIII-A dan IX-G}

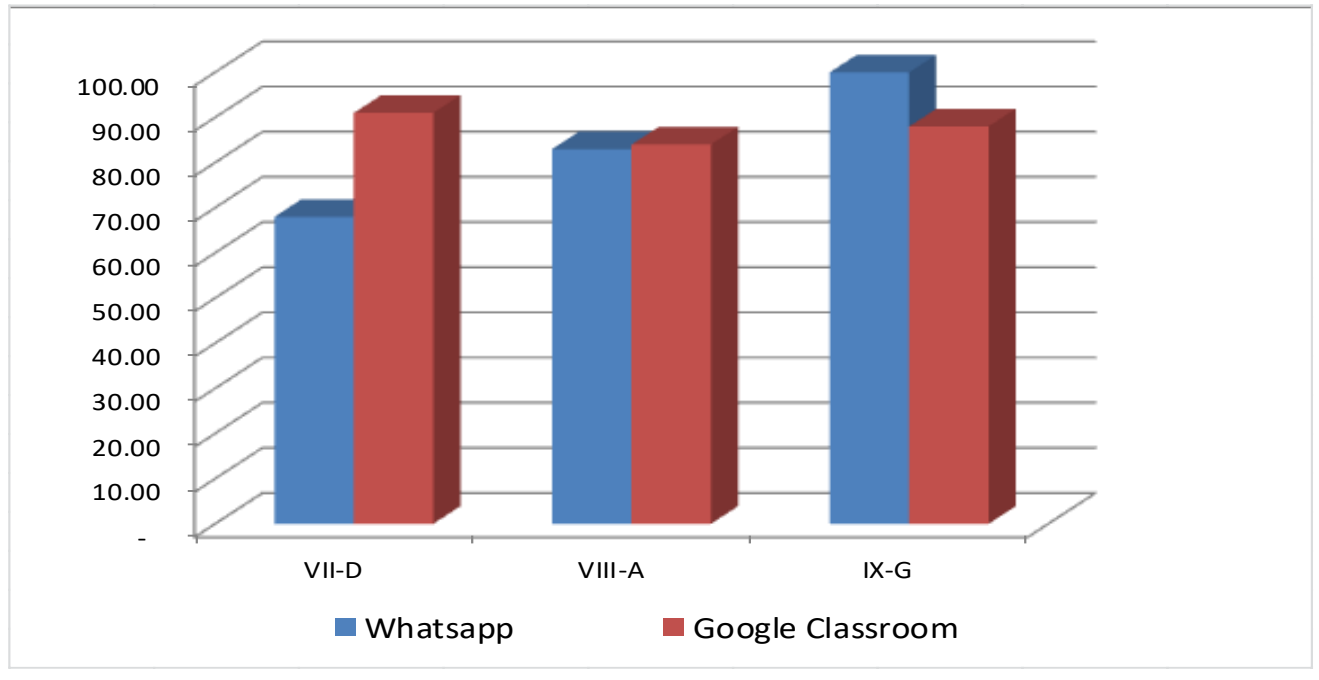

\section{Efektivitas Pemanfaatan Media Whatsapp dan Google Classroom dalam Pembelajaran Daring oleh Siswa.}

Penelitian efektivitas belajar siswa melalui media Whatsapp dan Google Classroom diambil dari data guru mata pelajaran. Sedangkan survey kepada siswa langsung berupa angket kepada 25\% siswa. Efektivitas pembelajaran daring ini dapat dilihat dari dua faktor, yaitu 1) partisipasi/keaktifan siswa dan 2) ketercapaian hasil belajar siswa dalam memenuhi target kompetensi minimal (KKM).

\section{a. Partisipasi/Aktivitas Siswa dalam Forum Pembelajaran Daring}

Keaktifan siswa dalam proses pembelajaran melalui media daring diperoleh data sebagaimana berikut: Kelas VII-D, dari 32 siswa yang aktif menggunakan Whatsapp dan Google Classroom sebanyak 66\% siswa. Di Kelas VIII-A, rata-rata siswa yang aktif menggunakan Whatsapp dan Google Classroom sebanyak 70\%. Untuk siswa kelas IX-G, dari 38 siswa, rata-rata yang aktif di Whatsapp dan Google Classroom $67 \%$ siswa. Secara detail data keaktifan diperoleh sebagai berikut:

Tabel 4. Keaktifan/Partisipasi Siswa mengikutii Pembelajaran Daring

\begin{tabular}{|c|c|c|c|c|c|c|c|}
\hline \multirow{3}{*}{ No } & \multirow{3}{*}{ Mapel } & \multicolumn{2}{|c|}{ VII-D (32 siswa) } & \multicolumn{2}{|c|}{ VIII-A (36 siswa) } & \multicolumn{2}{|c|}{ IX-G (38 Siswa) } \\
\hline & & \multicolumn{2}{|c|}{ Jml Siswa Aktif di } & \multicolumn{2}{|c|}{ Jml Siswa Aktif di } & \multicolumn{2}{|c|}{ Jml Siswa Aktif di } \\
\hline & & WA & $\mathrm{GCr}$ & WA & $\mathrm{GCr}$ & WA & $\mathrm{GCr}$ \\
\hline 1 & Quran Hadits & 26 & 16 & 30 & 23 & 25 & 25 \\
\hline 2 & Aqidah Aklak & 24 & 15 & 28 & 27 & 25 & 25 \\
\hline 3 & Fikih & 20 & 18 & 24 & 23 & 30 & 30 \\
\hline 4 & SKI & 21 & 21 & 23 & 24 & 24 & 23 \\
\hline 5 & Pkn & 24 & 19 & 26 & 25 & 27 & 27 \\
\hline 6 & Bhs. Indonesia & 24 & 20 & 28 & 26 & 25 & 25 \\
\hline 7 & Bhs. Arab & 23 & 12 & 28 & 24 & 27 & 29 \\
\hline 8 & Matematika & 30 & 30 & 26 & 21 & 24 & 10 \\
\hline 9 & IPA & 21 & 17 & 31 & 23 & 30 & 20 \\
\hline 10 & IPS & 24 & 22 & 30 & 22 & 27 & 24 \\
\hline 11 & Bhs. Inggris & 20 & 15 & 30 & 23 & 28 & 28 \\
\hline 12 & Seni Budaya & 22 & 22 & 27 & 24 & 28 & 28 \\
\hline 13 & Penjas & 27 & 23 & 26 & 19 & 24 & 22 \\
\hline 14 & Prakarya & 21 & 21 & 24 & 23 & 24 & 21 \\
\hline 15 & Bahasa Jawa & 22 & 12 & 24 & 19 & 29 & 26 \\
\hline & Rata-rata & 23 & 19 & 27 & 23 & 26 & 24 \\
\hline $\mathrm{Pet}$ & sentase Rata-rata & $73 \%$ & $59 \%$ & $75 \%$ & $64 \%$ & $70 \%$ & $64 \%$ \\
\hline & Rata-rata & & $66 \%$ & & $70 \%$ & & $67 \%$ \\
\hline
\end{tabular}




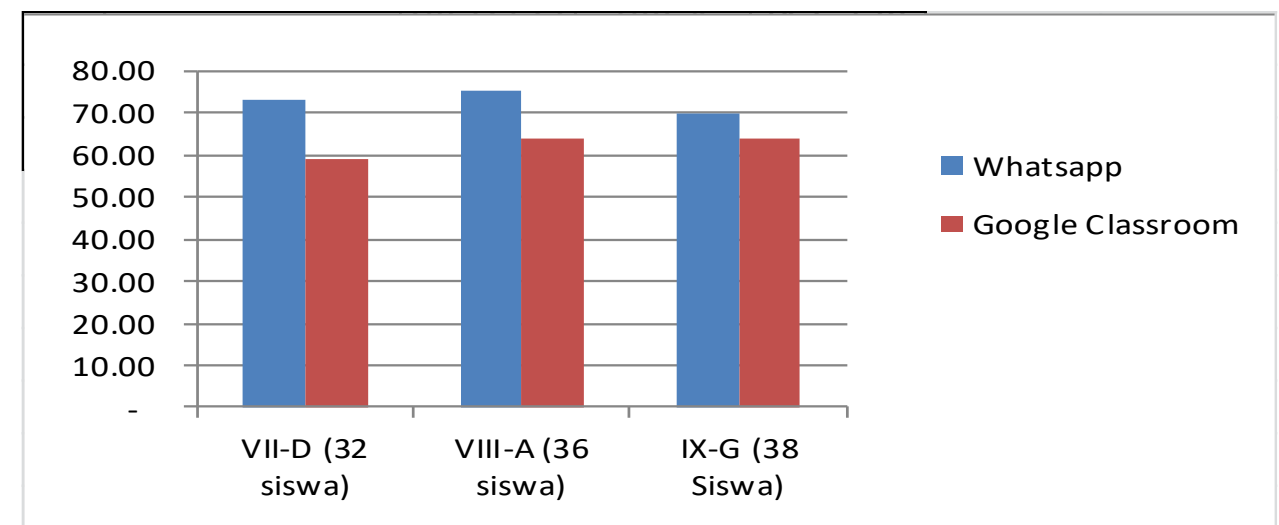

Grafik 5. Rata-rata Keaktifan Siswa mengikuti Pembelajaran Daring

\section{b. Tingkat Ketercapaian Kompetensi Minimal (KKM)}

Indikator efektivitas belajar yang paling utama adalah tingkat capaian tujuan pembelajaran itu sendiri. Tujuan pembelajaran tercapai secara maksimal maka dapat dikatakan pembelajaran mencapai efektivitasnya.

Dari hasil survey kepada guru mata pelajaran pada Penilaian Harian 1 sampai 3, ketercapaian KKM dapat diperoleh data sebagai berikut:

Tabel 5. Efektivitas Pembelajaran Daring (Indikator Ketercapaian Tujuan Pembelajaran)

\begin{tabular}{|c|c|c|c|c|c|c|c|}
\hline \multirow[t]{2}{*}{ No } & \multirow[t]{2}{*}{ Mapel } & \multicolumn{2}{|c|}{$\frac{\text { VII-D (32 siswa) }}{K K M=70}$} & \multicolumn{2}{|c|}{$\frac{\text { VIII-A (36 siswa) }}{K K M=70}$} & \multicolumn{2}{|c|}{$\frac{\mathrm{IX}-\mathrm{G}(38 \text { Siswa) }}{\mathrm{KKM}=70}$} \\
\hline & & $>=\mathrm{KKM}$ & $<$ KKM & $>=K K M$ & $<$ KKM & $>=K K M$ & $<$ KKM \\
\hline 1 & Quran Hadits & 26 & 12 & 30 & 8 & 25 & 13 \\
\hline 2 & Aqidah Aklak & 24 & 14 & 28 & 10 & 25 & 13 \\
\hline 3 & Fikih & 20 & 18 & 24 & 14 & 30 & 8 \\
\hline 4 & SKI & 21 & 17 & 23 & 15 & 24 & 14 \\
\hline 5 & Pkn & 24 & 14 & 26 & 12 & 27 & 11 \\
\hline 6 & Bhs. Indonesia & 24 & 14 & 28 & 10 & 25 & 13 \\
\hline 7 & Bhs. Arab & 23 & 15 & 28 & 10 & 27 & 11 \\
\hline 8 & Matematika & 30 & 8 & 26 & 12 & 24 & 14 \\
\hline 9 & IPA & 21 & 17 & 31 & 7 & 30 & 8 \\
\hline 10 & IPS & 24 & 14 & 30 & 8 & 27 & 11 \\
\hline 11 & Bhs. Inggris & 20 & 18 & 30 & 8 & 28 & 10 \\
\hline 12 & Seni Budaya & 22 & 16 & 27 & 11 & 28 & 10 \\
\hline 13 & Penjas & 27 & 11 & 26 & 12 & 29 & 9 \\
\hline 14 & Prakarya & 21 & 17 & 24 & 14 & 24 & 14 \\
\hline 15 & Bahasa Jawa & 22 & 16 & 24 & 14 & 29 & $\overline{9}$ \\
\hline \multicolumn{2}{|c|}{ Rata-rata } & 23.27 & 14.73 & 27.00 & 11.00 & 26.80 & 11.20 \\
\hline \multicolumn{2}{|c|}{ Persentase } & $72.71 \%$ & & $75.00 \%$ & & $70.53 \%$ & \\
\hline
\end{tabular}

Pembelajaran dikatakan tercapai bila $80 \%$ siswa memenuhi KKM yaitu 70. Dari data tersebut dapat diambil kesimpulan bahwa, tingkat ketercapaian pembelajaran di MTs Negeri 2 Purbalingga baru mencapai $73 \%$. Artinya, tingkat ketercapaian masih kurang.

Tabel 6. Indikator Nilai

\begin{tabular}{|l|l|}
\hline \multicolumn{1}{|c|}{ Nilai } & \multicolumn{1}{c|}{ Predikat } \\
\hline $91-100$ & Sangat baik \\
\hline $81-90$ & Baik \\
\hline $70-80$ & Cukup \\
\hline $0-69$ & Kurang \\
\hline
\end{tabular}

\section{Tanggapan Guru, Siswa dan Wali Murid tentang Efektivitas Pembelajaran Daring}

Survey ini meliputi dua hal, yaitu kelebihan dan kekurangan pembelajara daring melalui Whatsapp dan Google Classroom melalui angket terbuka. Artinya responden bebas 
mengemukakan pendapat tentang kelebihan dan kekurangan (kendala) dalam pembelajaran daring.

\section{a. Guru}

Dari 45 guru mata pelajaran, diperoleh keterangan bahwa 0\% guru mengatakan pembelajaran daring sangat efektif 51\% cukup efektif, 36\% menjawab kurang efektif, dan 13\% menjawab sangat tidak efektif. Alasan yang paling dominan tentang kelebihan dari pembelajaran daring adalah guru lebih tertantang untuk menggunakan teknologi, guru merasa dimudahkan dengan pembelajaran daring. Sedangkan kendala yang dominan adalah karena keterbatasan ruang untuk bisa menjelaskan materi pembelajaran.

\section{b. Siswa}

Dari hasil angket kepada 30 siswa, diperoleh data 86\% siswa menjawab pembelajaran daring sangat membantu dalam belajar, $0 \%$ cukup membantu dalam belajar, $14 \%$ menjawab kurang membantu dalam belajar, dan $0 \%$ menjawab sangat tidak membantu dalam belajar. Alasan yang paling dominan tentang kelebihan dari pembelajaran daring menurut siswa adalah karena waktu pengumpulan tugas lebih longgar.

Sedangkan alasan tentang kekurangan/kendala pembelajaran daring menurut siswa adalah tidak ada paketan $60 \%$, handphone rusak $11 \%$, malas belajar $11 \%$, ganti nomor Hp dan e-mail 5\%, sedangkan alasan lain-lain $13 \%$

\section{c. Orang Tua/Wali Murid}

Dari survei yang dilakukan peneliti ke 30 orang tua siswa, tentang efektifitas penggunaan WhatsApp dan Google Classroom, sebagai media pembelajaran mayoritas orang tua menyimpulkan $24 \%$ menjawab efektif, $53 \%$ kurang efektif, dan $23 \%$ menjawab tidak efektif.

Alasan yang paling dominan tentang kelebihan dari pembelajaran daring menurut orang tua siswa adalah kemudahan dalam mengakses materi pelajaran. Sedangkan alasan tentang kekurangan/kendala pembelajaran daring menurut orang tua siswa adalah kurangnya komunikasi dengan guru, orang tua melihat anak kurang semangat dalam belajar, orang tua tidak selalu bisa membantu kesulitan belajar anak.

Sesungguhnya pembelajaran daring membutuhkan effort yang besar dari guru dan orang tua, tidak sesederhana anggapan orang. Guru dan orang tua sebagai guru di rumah dituntut menciptakan lingkungan belajar yang integratif dan memenuhi berbagai komponen esensial pembelajaran yakni diskursif, adaptif, interaktif dan reflektif. Tentu ini harus diawali pemahaman yang sama antara guru dan orang tua.

Kehadiran guru secara virtual dalam pembelajaran daring sudah hampir mencapai $100 \%$, baik melalui Whatsapp maupun Google Clasroom. Namun model penyajian masih monoton, yaitu $100 \%$ materi disajikan menggunakan teks, $12 \%$ dalam bentuk video, $19 \%$ menyertakan gambar, $10 \%$ menyertakan quis online. Ini artinya pembelajaran daring harus belum bisa menciptakan suasana belajar yang komunikatif dan menyenangkan sebagaimana pembelajaran tatap muka.

Tingkat partisipasi siswa dalam forum pembelajaran daring masih kurang, yaitu baru mencapai $67 \%$. sedangkan $43 \%$ lainnya tidak aktif. Ini harus menjadi perhatian bagi guru dan orang tua untuk menemukan masalah dan sekaligus menemukan solusinya, sehingga seluruh siswa di kelas dapat mengikuti proses pembelajaran secara aktif.

Problem lainnya adalah kebosanan anak belajar setiap hari tanpa teman. Hampir 100\% anak menginginkan pembelajaran tatap muka di madrasah. Belajar bersama teman sekelas tentu berbeda rasanya dengan belajar di rumah sendirian atau hanya ditemani orang tua. Belajar di rumah juga mengakibatkan tidak adanya kompetisi positif antar teman yang mendorong siswa untuk belajar lebih baik.

Dari hasil survey, $48 \%$ siswa menerangkan tidak pernah ditemani/dibimbing dalam pembelajaran daring di rumah. 52\% mengatakan kadang-kadang. Artinya ini juga menjadi problem yang harus dipecahkan mengingat. Alasan yang paling banyak adalah karena orang tua tidak menguasai semua mata pelajaran anaknya. Alasan berikutnya adalah karena dilema 
dengan kesibukan bekerja. Orang tua tidak punya waktu mendampingi anaknya belajar karena sibuk bekerja.

Dari hasil penelitian di atas, sebagai bahan perbandingan, kita bisa melihat hasil penelitian lain seperti yang dilakukan oleh Ahmad Jafar S. (2020), mengambil kesimpulan bahwa Respon siswa dalam pembelajaran daring yang mayoritas menganggap membosankan serta tidak paham mengenai penjelasan guru.

Sementara Annisa M. (2020) menyimpulkan bahwa akibat adanya pandemic covid 19 pemerintah Indonesia menutup sekolah dan menjadikan menjadi pembelajaran online. Kegiatan pembelajaran online di rumah ini memiliki banyak kendala dan kekurangan seperti tidak semua anak mempunyai handphone, guru dan dosen masih banyak belum mahir mengajar dengan menggunakan teknologi internet atau media social, pembelajaran online cenderung memiliki banyak tugas, dalam pembelajaran untuk memahami konsep tidak berjalan dengan sebaik dari pada mengerjakan penugasan, lebih banyak pengeluaran pulsa maupun kuota internet untuk mendukung proses pembelajaran dan masih banyak lagi.

Namun pembelajaran online di rumah juga memiliki manfaat bagi siswa maupun orang tuanya. Manfaat-manfaat tersebut seperti pembelajaran online dirumah, dapat mempererat hubungannya dengan anaknya, tidak mengeluatkan biaya untuk uang jajan, dapat meningkatkan pengetahuan Teknologi, Informasi, dan Komunikasi (TIK) bagi siswa. Kebijakan ini, membuat kita semua sadar akan pentingngnya mempelajari teknologi dan menggunakan teknologi secara positif.

\section{KESIMPULAN}

Akhir dari penulisan hasil penelitian ini, dapat diambil beberapa kesimpulan bahwa bahwa pembelajaran daring melalui Whatsapp dan Google Classroom pada MTs Negeri 2 Purbalingga masih kurang efektif. Dari sisi partisipasi siswa dalam forum mencapai $67 \%$, dan dari ketercapaian tujuan pembelajaran $73 \%$ sudah mencapai KKM. Untuk mencapai angka ideal, maka sangat diperlukan peran guru, dan orang tua dalam meningkatkan efektivitas pembelajaran siswa secara daring di MTs Negeri 2 Purbalaingga.

Secara institusi harus dilakukan evaluasi dan perbaikan secara menyeluruh yang menyangkut faktor pendukung dan kendala yang dihadapi. Dalam hal ini pentingnya madrasah khususnya guru mengevaluasi diri terkait kinerjanya. Orang tua juga sudah saatnya mengevaluasi diri atas perannya dalam pembelajaran daring anak karena pembelajaran daring tidak bisa sepenuhnya diserahkan kepada madrasah dengan berbagai keterbatasannya.

Kedepan pembelajaran online ini perlu dievaluasi secara menyeluruh. Kapasitas guru dan kemampuan orang tua mesti menjadi salah satu bahan pertimbangan yang penting untuk membangun sistem pembelajaran daring yang efektif. Tidak lagi sistem pembelajaran daring rendah kualitas ditolerir dengan alasan disaat pandemi. Apalagi pandemi ini belum diketahui kapan akan bisa hilang. Kuat dugaan tidak akan terjadi dalam waktu dekat.

\section{DAFTAR PUSTAKA}

Ahmad Jafar S. dkk, (2020) Efektivitas Pembelajaran Daring Pada Siswa SMK di Kecamatan Petarukan. Universitas Negeri Semarang.

Annisa Maulidina F, dkk (2020), Analisis Dampak Pendemik Covid-19 : Proses Pembelajaran Online Dari Sudut Pandang Orang Tua di Desa Jamus. Universitas Negeri Semarang.

Astim Riyanto (2003) Proses belajar mengajar Efektif di Perguruan Tinggi, Yapendo Bandung.

Bosari (2013), Pemanfaatan Social Learning Network "Edmodo" Dalam Membantu Perkuliahan Teori Bodi Otomotif Di Prodi Ptm Jptk Fkip UNS, Jurnal Ilmiah Pendidikan Teknik dan Kejuruan 6(2) DOI:10.20961/jiptek.v6i2.12562

Moh. Ismail (2018), Model Pembelajaran Jarak Jauh. 
Nisaul Choiroh 2020, Efektifitas Pembelajaran Berbasis Daring/E-Learning Dalam Pandangan Siswa,

Surat Edaran Mendikbud Nomor 3 Tahun 2020 tentang Pencegahan Corona Virus Disease (COVID-19) pada Satuan Pendidikan

Zimmerman dan Martinez-Pons. 1990. Student Differences in Self-Regulated Learning Relating Grade Sex and Giftedness to Self Efficacy and Strategy Use March 1990. Journal of Educational Psychology 82(1):51-59 